\title{
Az EGYETEMI KÖNYVTÁRAK SZEREPE A NYÍLT TUDOMÁNY MOZGALOM ELTERJESZTÉSÉBEN
}

\author{
Hoczopán Szabolcs \\ Molnár Tamás
}

Az egyetemi könyvtárakban - különösen az SZTE Klebelsberg Könyvtárban - az Open Science előfutárai a szüken vett Open Access és a Szerzői Eszköztár ${ }^{1}$ oldalunkon az évek során kiépült szolgáltatásaink voltak. Közéjük tartozik például az intézményi nyílt publikációs díj támogatási rendszer², a publikálást közvetlenül támogató szolgáltatásaink (lektorálás, folyóirat-ajánló, plágiumkereső, publikációs e-learning felület és előadások, predátor folyóiratazonosítás, szerzői jogi tanácsadás), az OJS folyóirat-platformunk ${ }^{3}$, a jelenleg is épülő OMP e-könyv platformunk, DOI irodánk és zöld Open Access vonalon a publikációrepozitóriumunk.

A „keményebb” Open Science-szel a kutatási adatmenedzsment feladatai kapcsán kezdtünk el foglalkozni, RDM tanácsadás, adatkezelésiterv-konzultáció és adatrepozitórium-választásban való segítségnyújtás formájában ${ }^{4}$.

\section{Az Open Access}

Az Open Access-publikálást támogató szolgáltatások immár hat évre tekintenek vissza az SZTE Klebelsberg Könyvtárban, és egyértelműen sikertörténetnek könyvelhetők el.

1 http://szerzoknek.ek.szte.hu/ (Utolsó megtekintés: 2021. 07. 30.)

2 Krisztina Muzs, Tamás Molnár, Szabolcs Hoczopán, Open Access pályázati rendszer technikai megvalósítása és a szerzók támogatása a Szegedi Tudományegyetemen = Networkshop 2019 Konferenciakötet. https://doi.org/10.31915/NWS.2019.15

3 http://www.ek.szte.hu/ojs/(Utolsó megtekintés: 2021. 07. 30.)

4 Zeller Rozália, Hoczopán Szabolcs, NAGY Gyula, Kutatási adatkezelést támogató szolgáltatás a Szegedi Tudományegyetemen = Networkshop 2021.

https://kifu.videotorium.hu/hu/recordings/42348 
A szolgáltatások gerincét természetesen a nyílt hozzáférés publikációs költségeinek támogatása adta. Az intézményi OA-támogatás maga a könyvtárban egy központosított rendszeren keresztül valósul meg. Ez a központosítás teszi lehetővé az igények minőség alapú szelektálását ${ }^{5}$, az intézményi anyagi lehetőségekhez és szerződésekhez való igazítását, majd a kézirat útjának egyengetését a kiadói rendszerben, hogy a megfelelő adatokkal (affiliációval, előfeltételekkel, kódokkal stb.) legyenek ellátva, így a megfelelő szerződés hatálya alá kerülhessen, és az elfogadást követően ne legyen probléma az APC kiegyenlítésével. A 2020-as év során majdnem 600 elbírált OA-támogatási igényből végül 340 SZTE-publikáció született meg.

A fentiekből adódik, hogy a Könyvtár feladata a folyamatosan változó Open Access publikációs lehetőségekről tájékoztatni az Egyetemet. Erre a célra minden létező csatornát megragadunk.

Az évek során a szerzőkkel való folyamatos kapcsolattartás, a rengeteg közös munka révén alkalmunk volt pontosan felmérni, hogy a szerzőinknek milyen területeken van szükségük publikációs segítségre, és amelyeken magunk kompetensek voltunk, újonnan indított szolgáltatások keretében nyújtottunk támogatást a kutatóknak.

Ezen felül az SZTE-szerzőkkel kialakult (többnyire jó) kapcsolatainkat felhasználtuk arra is, hogy minden létező informális és hivatalos módon terjesszük az Open Science üzenetét.

\section{OA FOLYÓIRAT-AJÁNLÓ SZOLGÁLTATÁS}

Az OA publikációs források négy formáját kezeljük jelenleg az egységes szabályrendszer szerint. Ezek az egyetem által az általános OA célokra szánt (sajnos évről évre kisebb) keretet, az EISZ által megkötött

5 http://szerzoknek.ek.szte.hu/tamogatott-oa-publikalas/ (Utolsó megtekintés: 2021. 07. 30.) 
transzformatív szerződések OA kvótái ${ }^{6}$, az SZTE által kötött Read and Publish szerződések kvótái és a tisztán Open Access kiadóknál való publikálásra dedikált keret. Sajnos ezek az Open Access források a leggondosabb tervezés mellett sem tartanak ki feltétlenül egy teljes éven keresztül. A korábbi évek során mindegyik keretünk esetében volt arra példa, hogy év közben merült le a pénzösszeg vagy a publikációs kvóta ${ }^{7}$, nem csekély felháborodást keltve a szolgáltatás folyamatosságában bízó, illetve az azt jogosan el is váró kutatók közt.

Az első, a kutatókat komolyabban segítő szolgáltatásunk, az OA folyóirat-ajánló ${ }^{8}$ a fenti probléma melléktermékeként született meg. Amikor a Taylor and Francis read and publish konzorcium országosan bedőlt a kiadó nem túl korrekt árképzési módszerei miatt ${ }^{9}$, vagy amikor a Frontiers és MDPI kiadókkal való együttműködést mondtuk fel (a kiadók finanszírozhatatlan, meghívásos alapú különszám-özön publikációs stratégiájuk miatt), szükségessé vált, hogy a hoppon maradt szerzőinknek egy alternatív, maximálisan megfelelő folyóiratot tudjunk ajánlani, és ezzel tompítani az adott forrás hiányát. Meglepő módon a szükségmegoldásnak indult kezdeményezés népszerű lett a szerzőink körében, a gyakorlatban is igazolódott, hogy jók az ajánlásaink, így adta magát, hogy elszakadva a tűzoltástól, olyan szerzőknek is rendelkezésre álljunk, akik még ténylegesen bizonytalanok a folyóirat-választásban, a megfelelő scope-pal rendelkező folyóirat megtalálásában. Az alapkeresést a szolgáltatás elindításának hivatalos időpontjától kezdve, opcionális elemekkel egészítjük ki, vagyis a szerzők bármilyen kívánságát (kvartilis, IF stb.) beépítjük a keresésbe. Találati listaként a

6 Péter Süтő, Az EISZ open access szerződéseinek gyakorlati tapasztalatai = Networkshop 2020 Konferenciakötet. https://doi.org/10.31915/NWS.2020.6

7 http://eisz.mtak.hu/index.php/hu/open-access/open-access-hirek/404-oakvotak-kimerulese-a-wiley-es-az-ieee-kiadoknal.html (Utolsó megtekintés: 2021. 07. 30.)

8 http://szerzoknek.ek.szte.hu/folyoirat-ajanlo/ (Utolsó megtekintés: 2021. 07. 30.)

9 http://eisz.mtak.hu/index.php/hu/363-a-magyar-konzorcium-nemhosszabbitja-meg-a-szerzodest-a-taylor-francis-kiadoval.html

(Utolsó megtekintés: 2021. 07. 30.) 
szerző a legrelevánsabb 5-10 OA folyóiratcímet kapja meg az igényelt adatokkal kiegészítve, azon belül a legjobb cím kiválasztása már a szerző feladata.

A szolgáltatás népszerűségét mutatja, hogy folyamatosan érkeznek a keresési igények, noha sokszor az igénylők a szolgáltatás honlapját meg sem találták, de már „hallottak a könyvtár szolgáltatásáról”.

\section{Predátor Azonosító sZOlgáltatás}

Hasonlóképpen a szükség és a gyakorlat hívta életre a predátor folyóirat-azonosító szolgáltatásunkat. Az alapprobléma jól ismert. Az Open Access árnyoldala a számos parazita folyóirat, melyek tudományos értékkel nem rendelkeznek ugyan, de borsos árat szednek be a szerzőktől, akik az anyagi veszteség mellett a publikációjukat is elvesztik így. Észleljük időről időre, hogy predátor kiadók környékezik meg az egyetemet, a szerzőinket, és kérik fel egy-egy cikk megírására a szakterület „vezető” folyóiratába. A valótlan állítások meglepően sok kutatót csábítanak el. Sajnos, az új predátor folyóiratok gyarapodó száma, illetve az egyértelmű kritériumok hiánya miatt, és mert hitelesnek tekinthető predátor listákat már senki sem mer készíteni ${ }^{10}$, a kutatóknak nincs mihez nyúlniuk, ha predátor-gyanús kiadó lép velük kapcsolatba. Jó esetben az OA-publikálás ügyintézése során keletkezett ismeretség kapcsán előzetesen kérdezték meg a könyvtár munkatársait adott folyóirat besorolásáról, rossz esetben pedig a kézirat beküldése után, amikor már sok mindent nem tehettünk.

Nyilvánvalóvá vált, hogy szerzőinknek szüksége van egy olyan fix szolgáltatásra, mely kifejezetten a rosszindulatú folyóiratoktól védi okket. A szolgáltatás népszerűsítésével pedig ${ }^{11}$ az alapproblémára is fel tudtuk hívni a figyelmet.

10 Grudniewicz, A., Moher, D., Cobey, K. D., Bryson, G. L., Cukier, S., Allen, K., Ardern, C., Predatory journals: no definition, no defence, Nature, 576(7786), 2019, 210. https://doi.org/10.1038/d41586-019-03759-y

11 http://szerzoknek.ek.szte.hu/predator-folyoirat-azonositas/ (Utolsó megtekintés: 2021. 07. 30.) 


\section{A LÁthatósÁG NÖVELÉSÉNEK KÖNYVTÁRI ESZKÖZEI AZ SZTE-S PUBLIKÁCIÓK ESETÉBEN}

A kutatók a Publish or Perish szorításában néha nagyobb erőfeszítést tesznek a cikkek számbeli gyarapításáért, mint a hivatkozások számának növeléséért. Ennek természetesen a régi beidegződéseken alapuló teljesítményértékelési rendszerek az okai, azonban a mai online világban ez utóbbira is nagy figyelmet kellene fordítani a kutatói életpálya felépítése során, hiszen a generációs váltás a kutatói világot is eléri: jönnek azok a generációk, akiknek az online jelenlét egyre természetesebb ${ }^{12}$. Az online disszeminációnak, valamint az online impact mérésének is kialakult már a módszertana ${ }^{13}$, amit érdemes akár egy-egy PhD képzés tematikájába is beilleszteni.

Az SZTE Klebelsberg Könyvtára a láthatóság növeléséhez kutatói szemszögből nézve inkább passzív, mint aktív eszközökkel járul hozzá. (Természetesen folyamatos a szerzői képzés is, de ez inkább tekinthető célzottnak, egyes kutatókra irányulóknak, mint tömegesnek. A célzott képzés része az is, hogy a könyvtár részt kért a $\mathrm{PhD}$ hallgatók képzésében, melynek keretében On-line szakirodalmazás címen tart kurzust, szót ejtve benne többek között az Open Access, Open Science kérdéseiről is).

Részvételünk ${ }^{14}$ az egyetemen született publikációk disszeminációjában a következő eszközök által valósul meg jelenleg:

12 Barton, C. J., Merolli, M. A., It is time to replace publish or perish with get visible or vanish: opportunities where digital and social media can reshape knowledge translation, British Journal of Sports Medicine, 2019, 53, 594-598. https://doi.org/10.1136/ bjsports-2017-098367

13 Ross-Hellauer, T., Tennant, J. P., Banelytė, V., Gorogh, E., Luzi, D., Kraker, P. et al., Ten simple rules for innovative dissemination of research, PLoS Comput Biol 16(4): e1007704, 2020. https://doi.org/10.1371/journal.pcbi.1007704

14 KeveHÁzi Katalin, Nyílt hozzáférés a gyakorlatban, TMT, 63 (5), 193-197. 


\section{REPOZITÓRIUMOK}

Az SZTE Klebelsberg Könyvtára tudományos eredmények tárolását önálló gyűjteményeken keresztül végzi. Van repozitóriuma a doktori disszertációknak, egyetemi kiadványoknak és az SZTE-n készült publikációknak.

Az Eprints saját statisztika pluginja szerint az indulás óta közel kétmillió letöltésnél jár a Publicatio repozitórium esetében, a népszerű letöltések közé a DOI-val nem rendelkező, főleg magyar nyelvű anyagok tartoznak.

Mindhárom repozitórium minősítve van, s a minősítésnek köszönhetően már részben fel lettek készítve későbbi láthatósági céljaink eléréséhez. Ehhez az MTA-KIK-ben működő Repozitórium Minősítő Bizottság ${ }^{15}$ iránymutatásait kellett a gyakorlatba átültetnünk. Ennek megfelelően kezdődött el repozitóriumaink következő adatbázisokban való regisztrációja: BASE, OpenDOAR, ROAR.

Az alábbi adatbázisban történt regisztrációk nagy segítségünkre voltak a repozitált tudományos eredmények terjesztésében:

\section{BASE}

$\mathrm{Az}$ egyik leghasznosabb lépés volt a $\mathrm{BASE} \mathrm{E}^{16}$-be történő regisztráció. $\mathrm{Ez}$ egy igen nagy lefedettséggel rendelkező keresőmotor (2021 szeptemberében 272406165 dokumentumot tartalmaz 9100 tartalomszolgáltatótól). A jelentősége nem is csupán a nagyságában rejlik, hanem abban, hogy ő maga is tovább szolgáltatja a metaadatokat más adatbázisok számára. Hogy melyeknek, azt sajnos kérésre nem árulták el, de kiterjedt kapcsolatainknak köszönhetően az évek során kiderült néhány hely, ahol a BASE-ből veszik az adatokat. Csak felsorolásképpen: Zotero (külön plugin segítségével), EBSCO Discovery Service.

15 Ma már Repozitóriumminősítő Szakbizottság.

16 https://www.base-search.net 
A repozitóriumaink mellett ide regisztráltunk néhány OJS-ben szerkesztett folyóiratot is, hiszen az OJS is biztosít OAI-PMH kimenetet, amin keresztül a BASE-be történő aratás megvalósulhat.

\section{UNPAYWALL}

Az Unpaywall egy alulról indult kezdeményezés, mely a zöld Open Access útját hirdeti, segítségével jelenleg 29 millió dokumentum érhető el legálisan. Szolgáltat Gold OA folyóiratokból származó cikkeket, valamint a zöld OA keretében cikkek postprint és preprint formájában elérhető változatát is. Itt kell megjegyeznünk, hogy az SZTE Publicatio repozitórium csak a cikkek megjelent és postprint változatát fogadja be. Az Unpaywall csak a DOI-val rendelkező dokumentumokat tartalmazza (így 2021 augusztusában az SZTE Publicatio repozitórium 14.039 dokumentumából így 4237-et indexel), korábban oaDOI volt a szolgáltatás neve, és a ráépülő plugin volt az Unpaywall. Ma már egységesen Unpaywall néven fut ez a hasznos szolgáltatás. Forrásai a PubMed Central, a DOAJ, Crossref és a Datacite. Ők maguk is számos más szolgáltatónak továbbítják a nyílt elérésű, DOI-val rendelkező dokumentumok metaadatait. Ezek köre egyre bővül, s mivel a metaadatok XML alapú tárolása lehetővé teszi a szemantikus web alapját képező gép - gép kommunikációt, egyre több szolgáltatás épül a kimenetükre, s egyre több alapszik közülük a mesterséges intelligenciára.

\section{CORE}

E betűszó a COnnecting REpositories-ből származik. A repozitóriumok és a folyóiratok láthatóságának növelését tűzte ki célul, különböző kapcsolódások kifejlesztésével. Ilyen például a CORE Recommender plugin ${ }^{17}$, mely a világ több repozitóriumában telepítve van, és a résztvevő repozitóriumokból ajánl az adott cikk témájához hasonló, nyílt hozzáféréssel elérhető cikkeket. Jelenleg közel 212 millió dokumentumot

17 Pontika, Nancy, Anastasiou, Lucas, Charalampous, Aristotelis, Cancellieri, Matteo, Pearce, Samuel, Knoth, Petr, CORE Recommender: a plug in suggesting open access content, 2017. http://hdl.handle.net/1842/23359 
tartalmaz a világ minden tájáról. A Publicatio repozitóriumban a CORE Recommender plugin nincs telepítve, mivel a felhasználóink zöme célirányosan érkezik az általuk keresett publikáció elérésére, ezért egyelőre az elsődleges repozitóriumi cél a láthatóság növelése, a szakirodalmazás elősegítése csupán a távolabbi célok között szerepel.

\section{OPENAIRE}

Az OpenAIRE az elmúlt tíz év során igen nagy fejlődésen ment keresztül. A repozitóriumhoz fejlesztett plugin célja elsősorban az volt, hogy az EU FP7-es projektjeiből származó publikációkat arathatóvá tegyék az OpenAIRE számára, új metaadatmezők hozzáadásával OAIPMH kimeneten át. Ez a plugin lehetővé tette később a H2020-as projektek $^{18}$ és az OTKA projektek publikációs kimenetének mérését a repozitóriumon belül.

Miután az OpenAIRE lehetőséget biztosít repozitóriumok regisztrálására is, ezért az Egyetemi Kiadványok és a Publicatio is regisztrálva lett ide. Jelenleg, ahogy változik az OpenAIRE, s egyre inkább az Open Science minél teljesebb körű kiszolgálására törekszik, úgy lesz egyre több kapcsolódó szolgáltatása.

\section{OJS FOLYÓIRAT PLATFORM}

Az Open Journal System, online folyóirat-szerkesztő és -megjelenítő rendszer, nevével ellentétben, nem a nyílt hozzáférést szolgálja feltétlenül, csupán a szoftver maga nyílt hozzáférésű. A használata lehetőséget ad előfizetéses folyóiratok létrehozására és kezelésére is ${ }^{19}$.

18 Nyílt hozzáférés és Nyílt adat a Horizon 2020-ban Miben segíthet az OpenAIRE?, OpenAire Horizon 2020 Tájékoztatók https://openscience.hu/wpcontent/ uploads/2019/03/oa_tajekoztato_projektkoordinatoroknak_20181013_ magyar.pdf

19 Holl András, Bilicsi Erika, Nyílt publikálási szoftverek és platformok = Networkshop 2019, szerk. Tick József, KoKas Károly, Holl András, 2019. április 23-26., Széchenyi István Egyetem, Győr-Budapest, Hungarnet, 2019, 7, 54-60, https://doi.org/10.31915/NWS.2019.7 
Az SZTE Klebelsberg Könyvtárban akkor indult e rendszer kipróbálása, amikor annak 3.0-ás verziója elindult, így elkerülhetővé vált a sok problémával járó verzióváltás. A célzott felhasználók az Egyetemi Kiadványok repozitóriumának feltöltésekor megismert működő szerkesztőségek voltak. E folyóiratok többsége itt-ott, tanszéki honlapokon létezett, némelyik a Google által sem volt könnyen megtalálható. Többnyire mindössze 100-150 példány nyomtatott szám állt belőlük rendelkezésre (a nyomdai költségek miatt), és azok terjesztése is elég esetleges volt.

A szerkesztőségek beköltözését eleinte egy belső pályázat segítségével, később a pozitív példákon keresztül motiváltuk. Felismerték, hogy a korábbi, e-maileken történő szerkesztési folyamat felváltása egy komplett szerkesztőségi keretrendszerrel, milyen előnyökkel jár.

Jelenleg a tanszékek tisztában vannak azzal, hogy akár a folyóiratalapítás is könnyebben megy akkor, ha ezt a rendszert használják.

A könyvtár vállalta, hogy segít a felkészülésben, abban, hogy az adott folyóiratot a későbbiekben a Scopus, illetve a Web of Science befogadja. Ezek elég nagy célok egy-egy egyetemi folyóirat számára, de lesznek olyanok, akik elérhetik ezt.

Az egyetemi könyvtár a DOI-számok regisztrációjával, a Scopus, WoS követelmények ismertetésével, és gyakran az idejétmúlt formák naprakésszé tételében tud segíteni.

Az SZTE Klebelsberg Könyvtár figyelemmel kíséri az MTA-KIKben működő folyóiratminősítő bizottság kezdeményezéseit is, és ezekről folyamatosan konzultál a szerkesztőségekkel is. Tudatosítani kellett bennük például, hogy léteznek állandó azonosítók, melyeket használtatni kell a szerkesztőségi folyamat során (ORCID, DOI). Vannak tudományterületek, ahol a források és a hivatkozások közötti differenciálásra kellett felhívni a figyelmet. Számos esetben kellett rámutatni arra, hogy az online felületen lévő cikkek, PDF fájlok önálló 
életre kelhetnek, ezért az egyes cikkeken mindig fel kell tüntetni azt, hogy honnan „származnak”.

Munkánk eredményeként 21 folyóirat-szerkesztőség dolgozik már aktívan OJS platformunkon, és legalább 4 szerkesztőséggel zajlanak már a beköltözési elókészítő munkálatok. Apró, de inspiráló sikernek tekintjük, hogy a platformon való megjelenést követően folyóirataink nagy részéért már sorban álltak az adatbázis aggregátor cégek, a ProQuest és az EBSCO. Tematikus adatbázisaikban való megjelentetéssel is folyóirataink láthatóságát segítették elő.

Sajnos, az OJS nagy hátránya az, hogy kevés a testreszabhatósági lehetősége, viszonylag ritkák a hozzá írott pluginok, és néha úgy tűnik, hogy a fejlesztők távol tartják magukat a korszerủ folyóirat-működtetési normáktól, azaz az igényeket távolról követik csak. Így fordulhat az elő, hogy a láthatóságról nem lehet teljes képet alkotni.

\section{DOI}

A Digital Object Identifier önmagában nem járul hozzá egy-egy cikk idézettségéhez, noha vannak arra utaló jelek, hogy néhány kutató ezt reméli ennek használatától.

Ez csupán egy technikai eszköz, mely nem tükrözi az adott digitális objektum minőségét. ${ }^{20}$ Tény, hogy a DOI által használt metaadat séma, mely elvileg egy teljes bibliográfiai leírást tartalmaz a dokumentumról vagy adatról, viszonylag megengedő, azonban minél teljesebb a leírás, annál jobb helyezést lehet elérni az adatbázisokban vagy például a CORE típusú ajánlórendszerekben.

Az SZTE Klebelsberg Könyvtárában a DOI-igénylés a Crosref felé feltöltött XML segítségével történik, ügyelve arra, hogy az a hivatkozásjegyzéket és a támogatási adatokat is tartalmazza.

20 Bilicsi Erika, Hazai folyóiratok minősitése a Magyar Tudományos Müvek Tára alapján, Belügyi Szemle, 69(5), 2021, 723-733. https://doi.org/10.38146/BSZ.2021.5.1 
(Az OJS DOI pluginja, sajnos, hibás, nem jön ki minden adat, mely a rendszerben szerepel, illetve vannak hiányos adatok is, így az ottani kimenet mindenképpen korrekcióra szorul.)

Az SZTE Klebelsberg Könyvtára mindig is elkötelezett marad, és minden segítséget megad a szerzőknek, publikációik, s remélhetőleg hamarosan kutatási adataik láthatóságának növelése érdekében. Ennek a célnak az elérése érdekében segíti az egyetemen működő szerkesztőségeket is a minél jobb és egységesebb folyóirat-szerkesztési gyakorlat kialakításában, bízván abban, hogy hamarosan minél több „Scopus-kész" nyílt hozzáférésű folyóirattal fog az egyetem rendelkezni.

\section{Open Science és RDM KéRdőív}

2020. év végén, a Debreceni Egyetemi Könyvtár mintáját követve egy átfogó kérdőívet állítottunk össze, hogy felmérjük az SZTE kutatóinak elvárásait és igényeit az Open Science és különösképpen a kutatási adatkezelés terén ${ }^{21}$. A kérdőívre meglepően sok válasz érkezett, ami önmagában is jó jelnek számított, hiszen mutatta, hogy a kutatóinkat foglalkoztatja a téma.

A kérdőív válaszait kiértékeltük ${ }^{22}$, és a továbbiakban azok alapján igyekszünk meghatározni, milyen irányba is kellene folytatnunk a munkát az Open Science területén. A jelzett igények alapján több szolgáltatást, némi önképzést követően, már el tudtunk indítani 2021 elején ${ }^{23}$, más igényelt szolgáltatások, mint például az intézményi adatrepozitórium megépítése, még váratni fog magára, hiszen túl van jelenlegi lehetőségeinken.

21 Zeller Rozália, Hoczopán Szabolcs, NAGy Gyula, Kutatási adatkezelést támogató szolgáltatások elókészítése a Szegedi Tudományegyetemen kérdőív és válaszok [Data set], Zenodo, 2021. https://doi.org/10.5281/zenodo.5166625

22 Zeller Rozália, Hoczopán Szabolcs, Nagy Gyula, Kutatási adatkezelést támogató szolgáltatások elókészitése a Szegedi Tudományegyetemen, Tudományos Műszaki Tájékoztatás, 68. évf. 7. sz. (megjelenés alatt)

23 http://szerzoknek.ek.szte.hu/szolgaltatasaink Utolsó megtekintés: 2021. 07. 30. 


\section{ELINDÍTOTT KUTATÁSI ADATKEZELÉSI SZOLGÁLTATÁSOK}

\section{AdatrepozitóRIUm-AjÁnló}

Az Adatrepozitórium-ajánló volt a legkézenfekvőbb szolgáltatás, amelyet el szerettünk volna indítani az RDM kapcsán. Az Open Science-ben a publikációkhoz kapcsolódó, azokat alátámasztó adatcsomagok repozitálása amellett, hogy egyre inkább pályázati, kiadói elvárás, a láthatóság növelése miatt a kutatóknak is érdeke, hiszen a publikáció és a dataset is idézhető a kiadott DOI-k révén. Ráadásul a két objektumazonosító össze van kötve, ennek köszönhetően pedig az adatcsomagra érkező hivatkozás számít a publikációnál is, és természetesen ugyanez érvényes fordítva is.

A legmegfelelőbb adatrepozitórium megtalálása mégsem triviális a szerzők számára, akik nehezen barátkoznak meg a feladattal. De jelenleg még az adatrepozitórium infrastruktúra is éppen csak épülőfélben van, így bizonyos tudományterületek nincsenek megfelelően ellátva repozitóriumokkal. Az intézményi adatrepozitóriumok pedig ugyancsak tervezőasztalon vannak még Magyarországon, így azokra sem támaszkodhatunk.

Mindezeket figyelembe véve, elsősorban a legmeghatározóbb pályázati, fenntartói és kiadói ajánlások alapján próbálunk repozitóriumot ajánlani a kutatónak. Ha ezek nem adnak semmilyen támpontot, a DataCite DOI-szolgáltató ügynökség által összeállított Re3Data repozitóriumkereső ${ }^{24}$ segítségével folytatjuk a keresést, ahol a szűkítő facetták révén juthatunk el a kívánt találatokhoz. Ha esetleg nem találunk megfelelő diszciplináris repozitóriumot, akkor egy megbízható és minden igényt kielégítő multidiszciplináris adatrepozitóriumot javaslunk, mint például a Zenodo vagy a Figshare.

24 Registry of Research Data Repositories. Utolsó megtekintés: 2021. 05. 30. https://www.re3data.org 


\section{KutATÁSI ADATMENEDZSMENT TANÁCSADÁS}

Mivel a tudatos kutatási adatmenedzsment még viszonylag friss téma a magyarországi kutatói körökben, a szolgáltatás keretében általános kutatási adatkezeléssel kapcsolatban kívánunk segítséget nyújtani az SZTE kutatóinak. A szolgáltatást konzultációs jelleggel terveztük, hiszen nem minden esetben adhatók egyszerű, pár soros válaszok.

A kutatónak és a könyvtárosnak mindenképpen közösen kell megtalálnia az RDM kérdésekre a megoldást. A kutató ismeri saját tudományterületének specifikus adattípusait, munkafolyamatait és mérőműszereit. A könyvtáros pedig a konzultáció során a fenti információk birtokában segítséget tud nyújtani a kutatónak a kutatási adatok rendszerezésében, optimalizálásában, a metaadatok és kutatási dokumentáció létrehozásában, a kutatási adatok FAIR alapelveknek való megfeleltetésében, valamint a biztonságos adattárolási módok kialakításában.

\section{Adatkezelési TeRV KONZultáció}

A szolgáltatás keretében a pályázatokhoz kötelezően benyújtandó adatkezelési tervek kitöltésében kívánunk segítséget nyújtani a kutatóinknak. Kezdettől fogva lendületet adott a szolgáltatásnak, hogy meghirdetése környékén volt esedékes az OTKA és az Élvonal pályázatok benyújtása, melyeknek 2021-től már kötelező eleme lett az adatkezelési terv készítése. Csatlakoztunk az NKFIH-EKK-HUNOR tíz + tíz alkalmas meetup sorozatához ${ }^{25}$, melynek során az adatkezelési terv kitöltéséhez szükséges elméleti és gyakorlati tudást próbáltuk átadni az OTKA és Élvonal pályázatok kitöltőinek. A meetup sorozat jó alkalom volt számunkra, hogy sokféle tudományterület változatos adatkezelési problémáival találkozhassunk, és így saját ismereteinket is bővíthessük, miközben a konkrét feladat kapcsán az Open Science minden lényeges pontját érinteni tudtuk az előadások során.

25 Kutatási adatkezelés meetupok - NKFIH-EKK-HUNOR szervezésében. https://ekk. org.hu/2021/06/28/a-felsooktatasi-konyvtarakban-a-kutatasi-adatkezelesrolis-szol-a-2021-es-ev/ (Utolsó megtekintés: 2021. 07. 30.) 
Az első tíz alkalmas sorozatról számos SZTE-s kutató lemaradt az alkalmazott létszámkorlát miatt, ezért - átvéve a debreceni kollégák kidolgozott előadásmenetét - az OTKA pályázatok beadási határideje előtt immár saját szervezésben indítottunk létszámkorlát nélküli online találkozókat, kifejezetten a Szegedi Tudományegyetem számára. Amellett, hogy ilyen módon sikerült konzultációs lehetőséget biztosítani minden érdeklődőnek, jó alkalom volt ez, hogy a könyvtár új szolgáltatását éles körülmények között is bemutassuk az egyetemnek, valamint immár új funkciónkban is megmutathassuk magunkat.

A saját szervezésű meetupokat követően folyamatosan érkeztek a megkeresések a kutatók részéről a véglegesnek szánt DMP-k ${ }^{26}$ utolsó ellenőrzésére, valamint a még kérdéses pontok tisztázására.

Az OTKA - Élvonal pályázatok, a maguk még nem túlzottan összetett adatkezelési terveivel ${ }^{27}$, számunkra is ideális gyakorlási, betanulási lehetőséget biztosítottak. Nagy öröm volt, amikor az NKFIH pályázatokon túl, az első Horizon és FP7 adatkezelési tervekkel is megkerestek minket SZTE-s kutatók, és azt tapasztalhattuk, hogy az európai uniós pályázatok esetén is releváns segítséget tudunk nyújtani.

\section{EsZKÖZTÁR - OS KOMMUNIKÁCIÓs CSATORNÁK}

Minden lehetőséget megadunk kutatóinknak a kollégáinkkal való kapcsolat felvételére. Szolgáltatásainkhoz egyedi, beszédes e-mail-cím tartozik, melyek mögött pedig legalább három-három képzett kolléga várja a megkereséseket.

A Szerzői Eszköztár honlapunk saját hírfolyammal rendelkezik, ahol minden szolgáltatásváltozásról tudósítunk, mely a publikációs támogatásra pályázó szerzőknek óhatatlanul is szembeötlik. Ettől

26 Data Management Plan

27 Kutatásiadat-kezelési terv „OTKA” K_2l, FK_21, PD_21, ANN_21, SNN_2l pályázatok benyújtásához. https://nkfih.gov.hu/palyazoknak/nkfialap/kutatasi-temapalyazat-k2l/palyazati-csomag/kutatasiadat-kezelesi-tervk2l-fk2l-pd2l-ann2l-snn21 (Utolsó megtekintés: 2021. 07. 30.) 
függetlenül az oldalnak saját tematikus Facebook csoportja is van, szerencsére szép számú követővel, ahol minden ilyen jellegű hírt tükröztetni tudunk. A Könyvtár által üzemeltetett szakreferensi hálózat és PR-csoport is segítségünkre van a hírek terjesztésében, hiszen olyan levelezési listákhoz és kari hírlevelekhez van hozzáférésük, melyek még több potenciális felhasználóhoz tudják eljuttatni az OA-val, 2021-től pedig már a szélesebb körü Open Science-szel kapcsolatos információinkat.

Az Eszköztár honlap rendelkezik egy központi kapcsolati űrlappal is, azok számára, akik nem jutnak el a szolgáltatások weblapjaihoz, vagy esetleg nem is tudják, hogy problémájuk milyen szolgáltatáshoz tartozik. Ennek megfelelően ezen az ürlapon az összes téma felelőse rajta van, a válaszadás pedig az előre maghatározott rend szerinti.

2021 tavaszán a SZTE Klebelsberg Könyvtár fö honlapján ${ }^{28}$ már használatban lévő chat alkalmazás verzióját frissítettük fel, majd a Szerzői Eszköztár honlapunkon is bevezettük öt különböző témakörben, amelyek gyakorlatilag lefedik a teljes szolgáltatási portfóliónkat. Természetesen ez esetben is megszerveztük, hogy a chat könyvtári oldalán a specialistáink üljenek, ámbár a folyamatos ügyelet megszervezése, öt különböző speciális témában párhuzamosan, mármár a lehetőségeink határán túl van.

Elsődleges célunk a chatszolgáltatással a kutatókkal való kommunikáció felélénkítése és közvetlenebbé tétele volt. Be kell ugyanakkor látni, hogy ennek a tájékoztatási „műfajnak” is megvannak a maga korlátai. Az érintett témakörök gyakran pontos, személyre szabott útmutatásokat, több körös konzultációt igényelnek, melyre más csatornák sokszor alkalmasabbnak tűnnek. Ebben a formában a chat leginkább „forgalomirányító” funkciót tölthet majd be.

28 www.ek.szte.hu 


\section{ÖsszeFOGLALÁs}

Eddig elért eredményeink talán magukért beszélnek; az egyetemi könyvtárak nyilvánvalóan lehetnek az Open Science zászlóshajói, és azoknakiskelllenniük.Ámehhezazútönképzésekkel,próbálkozásokkal, igényfelmérésekkel és megvalósított szolgáltatásokkal van kikövezve, vállalva az új vizeken való navigálás veszélyeit, majd leszűrve a tanulságokat. Mindenképpen szükség van olyan szakmai szervezetek segítségére, mint a HUNOR, illetve egymás támogatására. Nagyon fontos lenne ezen felül (és ezen a területen az SZTE-n rengeteg teendőnk van még) a szoros együttműködés az anyaintézmény kutatásért felelős egységeivel és döntéshozóival, mert enélkül nehezen tudunk kitörni saját, könyvtáros berkeinkből.

Azt továbbra is látni kell, hogy a fentebb felsorolt feladatok egyike sem hullott csak úgy a Könyvtár ölébe. Mindegyiket önerőből indítottuk, keresve az utunkat az új Open Science világban, de egyik sem olyan, amit az egyetem más egységei ne tudnának ellátni, ha a Könyvtár esetleg nem megfelelően teljesítene az adott területen. 


\section{Open Science \\ NYÍLT TUDOMÁNY MAGYAR SZEMMEL}


A Magyar Tudományos Akadémia Könyvtárának Közleményei Publicationes Bibliothecae Academiae Scientiarum Hungaricae

$45(120)$
UJ SOROZAT

SOROZATSZERKESZTő

GaÁlné Kalydy Dóra 


\section{Open Science \\ NYÍLT TUDOMÁNY MAGYAR SZEMMEL}

Magyar Tudományos Akadémia

KöNYVTÁr ÉS InFORMÁcIÓs KözPONT

BUDAPEST 2021 


\author{
Szerkesztette \\ GaÁlné Kalydy DóRA \\ Anyanyelvi lektor \\ MóNOK MÁRIA \\ Az irodalomjegyzékeket készítette \\ BudAI-KirÁLY TÍmEA \\ Tipográfia és tördelés \\ VAs ViKTória \\ ISBN 978-963-7451-73-7 \\ ISSN 0133-8862 \\ DOI 10.36820/MTAKIK.KOZL.2021.OpenS
}

Felelős kiadó: az MTA Könyvtár és Információs Központ főigazgatója

Nyomta és kötötte az Alföldi Nyomda Zrt., Debrecen

Felelős vezető: GYöRGy GÉzA vezérigazgató

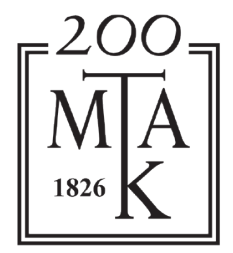

Megjelent a Nemzeti Kulturális Alap támogatásával

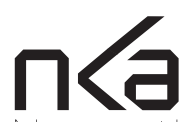

Nemzeti Kulturális Alap 


\section{TARTALOM}

\section{Monok István}

Cui bono, seu cui prodest?

Holl András

A tudományos szakkönyvtárak és a nyílt tudomány

(Open Science)

GaÁlnÉ Kalydy Dóra

A kiadókkal kötött Read and Publish szerződések, és a nyílt hozzáférésű publikálás hazai lehetőségei

Soós SÁndor, Kiss AnNA

Az „Open Access-előnyök" megnyilvánulása

a hazai tudásprodukcióban: bibliometriai hatásvizsgálat

61

\section{GaÁlné Kalydy Dóra}

A közösségi tudomány

\section{Tiberius Ignat}

What motivates us to develop the

Focus on Open Science series?

\section{Hoczopán Szabolcs, Molnár Tamás}

Az egyetemi könyvtárak szerepe a nyílt tudomány

mozgalom elterjesztésében

\section{Holl ANDrás}

Az MTA KIK gyakorlata a nyílt tudomány támogatásában $\quad 161$

A kötetben szereplő tanulmányok szerzői

A Magyar Tudományos Akadémia Könyvtárának

Közleményei, Új Sorozat közelmúltban megjelent kötetei 